\title{
Giving voice to the silent: a framework for understanding stakeholders' participation in socially-oriented initiatives, community-based actions and humanitarian operations projects
}

\author{
José Alberto de Camargo ${ }^{1}$ - Paulo Sérgio Miranda Mendonça ${ }^{1}$. \\ Jorge Henrique Caldeira de Oliveira ${ }^{1}$. Charbel José Chiapetta Jabbour ${ }^{2}$. \\ Ana Beatriz Lopes de Sousa Jabbour ${ }^{3}$
}

Published online: 20 February 2017

(C) The Author(s) 2017. This article is published with open access at Springerlink.com

\begin{abstract}
Under the umbrella of compassionate operations management theory (Sarkis, in Int J Prod Econ 139(2):359-365, 2012) and stakeholder theory, the aim of this article is to propose a comprehensive framework to unlock stakeholders' voice in socially-oriented projects (for example, social responsibility, community and humanitarian projects). The framework developed in this work aims to assist managers to measure the level of engagement of stakeholders during socially-oriented projects' execution. It may allow better accountability, transparency and stakeholder satisfaction. For this purpose, the study seeks to explore key concepts and ideas about participatory management in socially-oriented projects, and Freeman's (Strategic Management: a stakeholder approach. Pitman, Boston, 1984) stakeholder theory, in addition to essential principles of the AA1000 framework. It is therefore a piece of conceptual research based on the proposal of a framework. This framework could in the near future be applied to organizations that need to expand their level of awareness of stakeholders' satisfaction during the execution of organizational social responsibility and humanitarian project management they finance. It makes possible to understand the level of involvement of stakeholders. It is
\end{abstract}

Charbel José Chiapetta Jabbour

c.j.chiappettajabbour@stir.ac.uk

José Alberto de Camargo

josealcam@uol.com.br

Paulo Sérgio Miranda Mendonça

paulomiranda@usp.br

Jorge Henrique Caldeira de Oliveira

jorgecaldeira@usp.br

Ana Beatriz Lopes de Sousa Jabbour

ana.jabbour@strath.ac.uk

1 Faculty of Accounting, Economics and Management, University of Sao Paulo, Avenida Bandeirantes, 3900, RAD-FEARP, Ribeirao Preto, SP, Brazil

2 Centre for Advanced Management Education, School of Management, University of Stirling, University of Stirling Campus, Stirling, Scotland FK94LA, UK

3 Department of Design, Manufacture and Engineering Management, University of Strathclyde Glasgow, 75 Montrose Street, Glasgow, Scotland G1 1XJ, UK 
expected that the contributions made will be useful for researchers to propose new studies to improve the indicators presented here, as well as allow future studies to apply these indicators in social projects and in humanitarian initiatives.

Keywords Compassionate operations management - Stakeholders · Socially-oriented projects · Humanitarian projects · Social Project Management · Theory of Stakeholders

\section{Introduction}

Under the umbrella of searching for more compassionate operations management (Sarkis 2012), socially-oriented projects, including projects for community development, organizational social responsibility, and humanitarian initiatives, have been growing exponentially. However, the assessment of these projects, in terms of social gain, is still not conclusive. For example, sustainable humanitarian supply chains require not only agility, adaptability and alignment (Dubey and Gunasekaran 2016), but also positive social outcomes, showing the complexity of sustainable initiatives.

One challenge encountered during socially oriented projects (organizational social responsibility projects, community projects, and humanitarian projects management) is that the current frameworks for their analysis are in many cases the same as those available for management and evaluation of commercial projects, which can hamper a more comprehensive reading of the impact assessment of such projects (Sulbrandt 1994; Weiss 1998; Rodrigues 2010).

Sulbrandt (1994), Weiss (1998) and Rodrigues (2010) state that the existing management methods for socially-oriented projects are generally an adaptation of the methods used in commercial and business projects and do not consider relevant aspects in the evaluation of social projects such as the involvement of stakeholders.

Socially-oriented projects are necessary either when managing humanitarian support (Leiras et al. 2014), social responsibility initiatives (Carroll 1979) or corporate sustainability (Elkington 2001). They are an intrinsic part of the social dimension of corporate sustainability. However, social and humanitarian project management frameworks use, in their elementary structure, theoretical foundations and concepts initially provided for managing commercial and for profit projects, which would be inappropriate since according to Rodrigues (2010) socially-oriented projects have a management structure which can be considered different from commercial projects.

Tenório (2006) identifies four specific functions that make up project management: planning, organization, direction and control. First, the objectives are defined, and the way in which they will be achieved and the expected time will be outlined. Second, the responsibilities are assigned to each team member, according to the skills and competencies of each so that the objectives are achieved. The third function relates to the manager's ability to keep the team motivated to develop its tasks efficiently. In the fourth function the manager evaluates the results, comparing those obtained with the expected results, and corrects possible flaws and proposes improvements in the management plan and in its framework.

Chanlat (1995) views a project management framework as a set of management practices that are performed by organization management in order to achieve set goals, and which is influenced by factors such as working conditions and organizational style, hierarchy, types of structures, evaluation systems, and control of the results, values and philosophy, among others. There are two components in the management framework: the prescribed and the real. 
Chanlat (1995) explains that the first describes the framework as something ideal, and the second refers to a concrete and effective framework.

Tenório (2006) designates three types of measures as essential. The first is efficiency, understood as how the manager manages the resources available. The better the management of these resources with the activities to be developed, the more efficient the manager. The second measure is efficacy, whereby the manager fulfills their given objective. Being efficacious is to achieve the determined goal. The third is effectiveness: the ability to meet the expectations of society (Tenório 2006).

For Sulbrandt (1994), Weiss (1998) and Rodrigues (2010), a more comprehensivelyoriented framework of socially-oriented projects management should rely on the satisfaction of the beneficiaries and other stakeholders involved, in order to capture their perception of the management and to influence management in order to predict joint participation of the actors involved in these projects.

Although Sulbrandt (1994), Weiss (1998) and Rodrigues (2010) have pointed out the limitations of current methods for socially-oriented project management (for example, social responsibility and humanitarian projects), a new framework aiming to overcome this challenge is still to be presented. The new framework should include constructs such as the opinion/feedback of the beneficiaries and the perception of the stakeholders. Based on those gaps between reality and stakeholders' perception, this work aims to suggest a framework elaborated with constructs/variables which can be useful to assess the participation of stakeholders in socially oriented projects and humanitarian initiatives.

The originality of this work is based on:

- Socially-oriented projects need to be anchored in stakeholders' perspectives. However, there is still the opportunity to develop frameworks and theory further;

- The framework presented can be useful for organizations leading socially-oriented projects, in order to verify the level of "stakeholders' voice" during the process;

- The framework presented can be applied to a number of socially-oriented initiatives, such as humanitarian projects;

- The framework can have its main variables developed further by including them in mathematical or statistics models, with implications for operations management scholarship.

\section{Theory development}

\subsection{Organizations and stakeholders}

For Barbieri and Cajazeira (2007), organizations should see socially-oriented projects as a strategic factor, especially in the context of high competition and constant pressure from consumers, pushing organizations to care about the environment, quality of life of their employees and the preservation of their image in society.

Buchholz and Rosenthal (2005) understand that the organizational world has changed and, with it, consumers/users. Focusing only on maximizing shareholder profits is no longer the sole strategy used by organizations. In socially responsible management, social groups hitherto not considered by an organization, such as family members of employees, nearby communities, and non-profit entities, become members of the social responsibility process. Therefore, the expectations and needs of all stakeholders should be known and considered by project managers. 
Sustainability has been the subject of discussion in several countries and a common search for communities, governments and organizations. Barbieri and Cajazeira (2007) state that achieving it is something that we all seek, since it translates into a better world for present and future generations, without causing harm to the environment combined with a reduction of social disparities.

Freeman (1984) is the first to present the Theory of Stakeholders, defending the view that the responsibilities of organizations should be directed to all stakeholders, not just shareholders. For Donaldson and Preston (1995) all groups legitimately involved with an organization participate to obtain benefits. This would remove the chances of prioritizing certain interests over others.

Analyzing the way stakeholders link with and participate in socially-oriented projects depends on the understanding of the management processes by which social projects happen.

\subsection{Managing socially-oriented projects}

Civil society organizations are able to intervene in social reality when their social agents are skilled, and when they can create and apply new organizational concepts, for example, providing relief to humanitarian crises and disasters. Thus, social project management becomes an essential requirement for achieving the best performance possible of socially-oriented projects (Gaudeoso 2014).

According to the PMBOK Guide standard published by the Project Manager Institute (PMI) (2008), a project can be understood as a temporary endeavor undertaken to create a product, service or a unique result, and the temporary nature of a project indicates a defined beginning and a defined end. The term 'temporary endeavor' does not mean, however, that the project is of short duration and does not apply to the product, service or result created by the project, since most projects are carried out with the purpose of creating a lasting result, generating more environmental and economic social impacts that last longer than the project duration itself.

In relation to the phases of project management processes, the guide states that there is no single way to define the ideal structure for a project, and that it can have sequential development (a phase or process occurs independently of another) or overlapping (one step or process occurs at the same time as others).

According to the Project Management Institute (2008), the five steps are: (1) the beginning, (2) planning, (3) implementation, (4) monitoring and control or evaluation, and (5) closure. The last of these occurs when the goals are achieved or when it is concluded that it is not possible to achieve them.

A socially-oriented project can be defined, according to Rodrigues (2010), as a set of activities interrelated with each other to achieve specific objective of transforming social reality within the limits of budget and schedule, establishing a start and end point for the project. Although there are some similarities between the definition of projects and social projects, the author comments on the importance of developing an evaluation methodology specifically for socially-oriented projects within organizations. This perspective is based on the argument of Sulbrandt (1994), and the evaluation of social projects should include both a top-down analysis, using traditional assessment tools, and bottom-up analysis, which considers the voices from stakeholders.

Gaudeoso (2014) adds that the management of socially-oriented projects involves the adoption of management tools that allow an organization to control events within a scenario that considers time, cost and quality of services. 
A brief description of the five main frameworks used in project management is presented in Table 1.

After presenting the main guidelines for project management, it is important to consider other aspects in the management of corporate social projects.

\subsection{Desirable impact from social projects and stakeholders}

An analysis of the impact of socially-oriented projects from the perspective of stakeholders is based on the concept of perceived impact, taking into account the views of interested parties as predicted by Weiss (1998).

The idea of analyzing the impact of social projects was reinforced in the AA1000 (2008) standard, which proposes being accountable to shareholders and stakeholders as the organization's objective, and consists of recognizing and taking responsibility and maintaining

Table 1 Frameworks for evaluation of socially-oriented projects. Source Inspired by AA1000 (2008) and Rodrigues (2010)

Frameworks for managing socially-oriented Description
projects
projects

Inspiration: Logical Framework Developed by: United States Agency for International Development (USAID)

Inspiration: ZOPP

Developed by: GTZ

Inspiration: Program Theory

Inspiration: AA 1000 Developed by: ISEA-Institute of Social and Ethical Accountability-NGO based in the UK
Created as a planning tool to systematize social interventions. Its function is to make the process of conception, design and execution of a project easy. It began to be criticized in the 1980s for focusing only on filling the cells of a planning matrix, ignoring the possible relationship between design variables

ZOPP is considered a method that prepares and plans the implementation and evaluation of social projects. It arose in response to criticism of the logical framework. It does not ignore the logical framework, it simply uses it more broadly. Unlike the logical framework, the ZOPP method plans the results, execution and monitoring (evaluation) of a project, allowing for a more active participation of all parties involved

Created with the focus on project operation logic, this is a method of evaluation that was created to serve as a planning tool. It proposes a chain of hypotheses that explains how program activities will lead to the desired results. Program Theory aims to detail the key issues of planning, and verify that the assumptions made in the formulation of a project are consistent

This is a standard for sustainable organization practices. AA1000 is focused on ensuring the quality of accounting, auditing and social and ethical reporting. It consists of principles of process standards. Its goal is to support organizational learning and overall performance-social, ethical and economic-leading the organization towards the path of sustainable development. It has important points of contact with the theory of stakeholders to highlight the need for organizations to maintain dialogue and be concerned with the inclusion of stakeholders 
Table 1 continued

\begin{tabular}{|c|c|}
\hline $\begin{array}{l}\text { Frameworks for managing socially-oriented } \\
\text { projects }\end{array}$ & Description \\
\hline $\begin{array}{l}\text { Inspiration: CSA - Corporate Social Action } \\
\text { Developed by: Rodrigues (2010) }\end{array}$ & $\begin{array}{l}\text { This is an improvement of program theory that seeks to } \\
\text { incorporate dialogue with stakeholders in the process } \\
\text { of evaluation of social projects. It is based on the } \\
\text { search for the evaluation of individual and voluntary } \\
\text { actions of companies when they develop some kind of } \\
\text { action that brings benefits to the community. The } \\
\text { method aims to measure the impact of corporate social } \\
\text { action based on the identification of causal } \\
\text { relationships based on experimental logic and } \\
\text { qualitative data. The efficacy criterion seeks to } \\
\text { identify whether the results announced by the } \\
\text { organization are being achieved. One of the main } \\
\text { difficulties is to measure the involvement of the } \\
\text { various public groups linked directly or indirectly to } \\
\text { the organization in conducting social projects. While } \\
\text { stakeholders are heard in the evaluation process, they } \\
\text { do not participate in the stages of planning, } \\
\text { development and control of the projects (stakeholder } \\
\text { engagement), nor are the opinions of beneficiaries and } \\
\text { other stakeholders considered in the process. Another } \\
\text { criticism is that the efficacy criterion overlaps with the } \\
\text { dialogue of beneficiaries and other stakeholders }\end{array}$ \\
\hline
\end{tabular}

transparency about the impacts of decisions, actions, policies, products and performance associated with it.

According to AA1000 (2008), the AA1000 standard suggests that an organization involves stakeholders in identifying, understanding and also responding to issues and concerns about sustainability, and to report, explain, and be available to answer to stakeholders about its decisions, actions, and performance.

The AA1000 (2008) standard also includes the way in which an organization defines its governance framework and its respective strategies, and the way in which it manages its performance. The basic premise is that a responsible organization will work to define a strategy based on understanding and on a comprehensive response in relation to relevant issues and concerns of stakeholders. Thereby it can set goals according to which the strategy and the corresponding performance can be managed and evaluated, in order to disseminate credible information regarding strategies, objectives, standards and performance, basing its actions and decisions on that information.

According to AA1000 (2008), these actions are the basis for establishing, evaluating, and communicating accountability. Its principles encourage these actions to be based on principles, and the main principle, that which will compose this new social project evaluation methodology is that an organization should be inclusive. That is, an inclusive organization is accountable for impacts (community, environment, internal and external stakeholders).

As envisaged in the AA1000 (2008), inclusion is the participation of stakeholders in developing and achieving a strategic and responsible response in relation to sustainability.

Stakeholders are all individuals, groups of individuals or organizations that affect and/or may be affected by the activities, products, or services corresponding to the performance of an organization (AA1000 2008). 
Therefore, inclusion is more than a process of involving stakeholders. The concept of inclusion proposes that stakeholders participate in identifying problems and contribute to the management of solutions in organizations. It consists of cooperation at all levels, and an organization should establish a governance framework in order to achieve better results (AA1000 2008).

Basically, social project management within the AA1000 (2008) standard, seeks to assess and provide conclusions about the nature and the level of adherence to the principles of AA1000, and about the quality of information made publicly available for sustainable performance with focus on the evaluation of relevance and responsibility or response capacity, according to the principles of inclusion (Table 2).

According to AA1000 (2008), inclusion is the starting point to determine relevance, since this process decides the issues of highest priority for an organization and its respective stakeholders.

By the principle of relevance, organizations should identify what the materially relevant issues are which influence the decisions, actions and performance of an organization and its respective stakeholders. The relevant topics are determined from a process of determining priorities. Thus, the information is analyzed in a comprehensive and balanced manner.

Such information may be financial or not. Non-financial data are the vectors that promote sustainability and its impact on stakeholders, who should be included as information sources. The time period can be considered as short, medium and long term.

In analyzing the information, an organization should consider the elements that encourage sustainability and also its needs, concerns, and expectations as well as those of its stakeholders. Finally, the organization will select the most relevant issues to stakeholders. This process must be in line with the decision-making and development strategies of the organization.

Responsibility consists of the decisions, actions and performance in relation to important matters. It occurs when an organization establishes criteria which make it able to address the concerns of stakeholders that affect its sustainable performance. Establishing effective communication with its stakeholders is key. Thus, decision-making will be well founded since replies given by the organization will seek to meet the needs and expectations of stakeholders.

\subsection{Management of socially-oriented projects}

Scientific studies, related to this research, were selected to discuss new approaches to the management of social projects.

Using the ideas of Roche (2000) and Santos (2004), four key elements of impact assessment in specific stages of the project cycle can be exposed: review, identification, implementation and evaluation. The review should be undertaken before, during and after the project, in order to assess the performance and impact of the action. Identification is an initial analysis of the historical situation, trends and the expected impact of interventions, allowing the creation of indicators for measuring. Implementation is the collection and analysis of indicators. Finally, evaluation is a detailed review of the performance, costs, benefits and impact of the proposed social action. Roche (2000) and Santos (2004) also state that projects should not repeat the same cycle continuously, since there are continual improvements resulting from organizational learning and constant improvement of management processes.

Another study by Coutinho et al. (2006) presents a management framework of corporate social projects. One of its main constructs is the satisfaction of stakeholders, i.e. the local community, the project team, employees of an organization and even the public authorities. In order to address the management and evaluation of social projects from the point of view of inclusion and participation of stakeholders, Salazar et al. (2012) holds the view that both 
Table 2 Principles of adherence to the AA1000 standard. Source Inspired by AA1000 (2008)

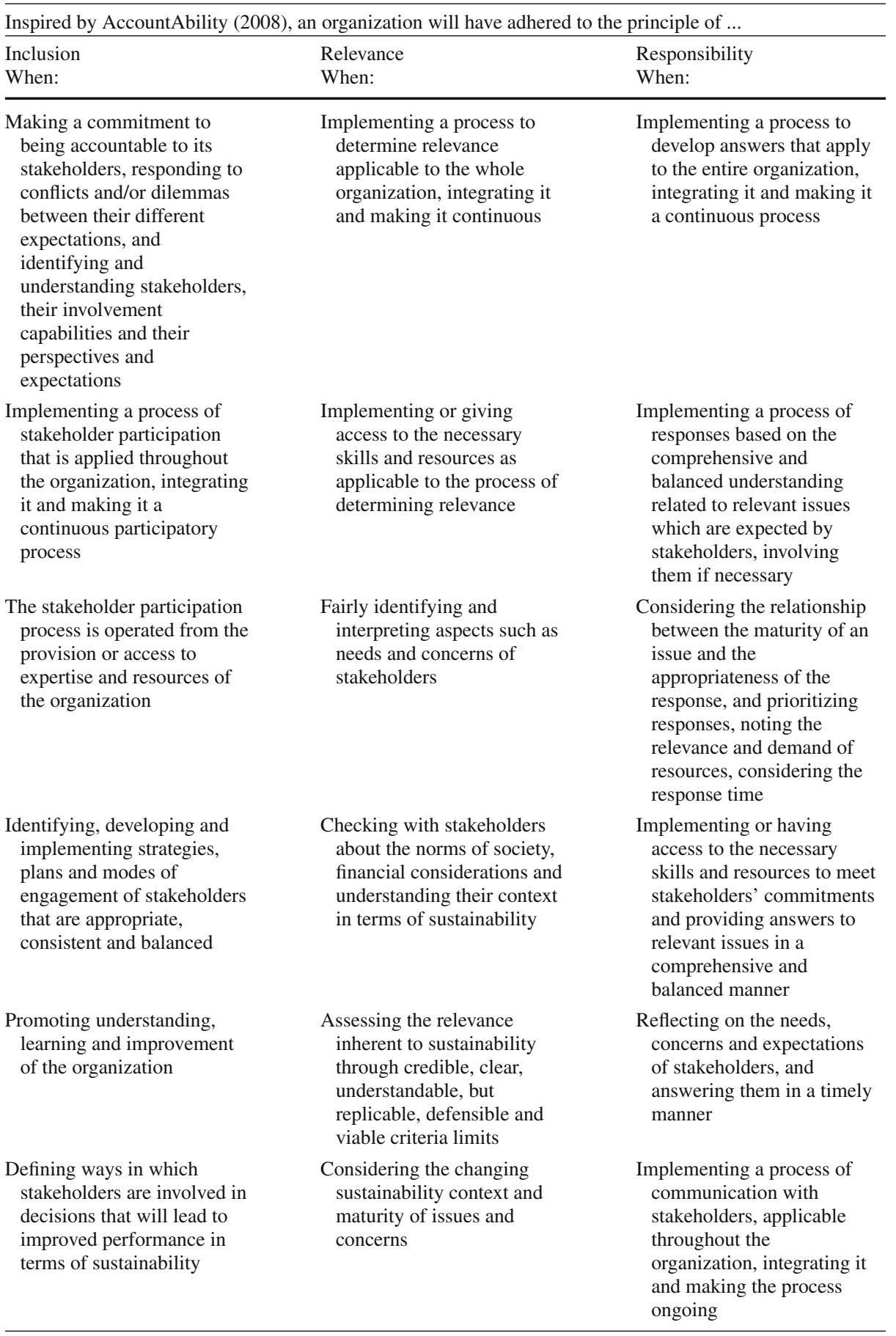


Table 2 continued

\begin{tabular}{|c|c|c|}
\hline \multicolumn{3}{|c|}{ Inspired by AccountAbility (2008), an organization will have adhered to the principle of ... } \\
\hline $\begin{array}{l}\text { Inclusion } \\
\text { When. }\end{array}$ & $\begin{array}{l}\text { Relevance } \\
\text { When. }\end{array}$ & $\begin{array}{l}\text { Responsibility } \\
\text { When. }\end{array}$ \\
\hline $\begin{array}{l}\text { Increasing involvement } \\
\text { capacity of the internal } \\
\text { stakeholders and supporting } \\
\text { the increase of capacity } \\
\text { externally }\end{array}$ & $\begin{array}{l}\text { Including a way to respond to } \\
\text { conflicts and/or dilemmas } \\
\text { resulting from different } \\
\text { expectations regarding } \\
\text { relevance }\end{array}$ & $\begin{array}{l}\text { Covering, balancing, } \\
\text { identifying weaknesses and } \\
\text { preventing misreporting, } \\
\text { being accessible to } \\
\text { interested parties through } \\
\text { appropriate reporting, } \\
\text { principles, structures or } \\
\text { guidelines }\end{array}$ \\
\hline
\end{tabular}

the organization and beneficiaries of social projects can make use of relevant knowledge gained during and after their implementation.

Valdes-Vasquez and Klotz (2013) address the evaluation of sustainable projects, also from the perspective of beneficiaries. This study addresses sustainability in its social dimension which is defined by the engagement of all stakeholders in order to ensure that the needs of current and future populations are met. Five propositions were made by the authors: (1) stakeholder engagement ensures the formulation and development of corporate social projects with the involvement of managers, employees and beneficiaries; (2) greater consideration of the opinion of the beneficiaries also contributes to the formulation and development of these projects with the involvement of managers, employees and beneficiaries, (3) the involvement of these actors is achieved through good management of internal stakeholders, (4) it is expected that the same engagement is achieved through the assessment of impacts and results of social projects; and (5) consideration for the community and attributes associated with the organization would contribute to the involvement of these managers, employees and beneficiaries of the same projects.

After reviewing the literature, it is possible to suggest some research gaps that remain a rich opportunity for future research

- Under the umbrella of compassionate operations management (Sarkis 2012) theory and stakeholders' theory, who are the main stakeholders for socially-oriented projects?

- What framework would best help managers to measure the engagement of stakeholders during the execution of socially-oriented projects?

- What would be some of the most relevant subjects for a future research agenda on assessing participation of stakeholders for socially-oriented projects?

Section 3 aims to contribute to this debate. 


\section{Proposal of a framework for assessing stakeholders' participation in socially-oriented projects}

Socially-oriented projects should incorporate the theory of stakeholders, by engaging in the participation of stakeholders in the management process promoted by an organization, which opens the assumption that listening to views of stakeholders could be incorporated as part of the management and impact of social projects.

From this reflection, after consulting the literature, a variety of variables were selected and sorted into five constructs in order to suggest a framework for socially-oriented project management. The constructs were partially adapted from the work of Valdes-Vasquez and Klotz (2013). Although they focus on the social dimension of sustainability, covering projects in the construction industry, it also enables an application in social projects because it contains several points that can be adapted for this purpose.

The work of Valdes-Vasquez and Klotz (2013) was chosen as a reference for the categories of constructs because the approach of these authors includes both the basis of the Theory of Stakeholders and consideration of the views of beneficiaries, as outlined by authors such as Salazar et al. (2012), Sulbrandt (1994), and Weiss (1998). Other variables from studies in the field of the Theory of Stakeholders, such as Clarkson (1995), Marrewijk (2003), Buchholz and Rosenthal (2005), Gilbert and Rasche (2008), Rodrigues (2010), Purnell and Freeman (2012), and Harrison and Wicks (2013), were included in the five constructs in order to analyze different aspects relevant to the involvement of stakeholders in participatory management of social projects.

The first construct "engagement" is the involvement and participation of stakeholders in all processes of a socially-oriented project. Planning, organization, implementation and control should involve stakeholders so that they participate in actions promoted, and in the decisions taken by management.

The second construct "opinion from beneficiaries" is the evaluation of the impact on beneficiaries, i.e. to evaluate the involvement with beneficiaries within the social projects of an organization, as well as their inclusion in the management and dissemination of the results of these projects. It also involves listening to the beneficiaries before, during and after the completion of the project.

The third construct "the management of internal stakeholders" is to assess the training of the staff who will work on the social project financed by the organization, considering the needs of the beneficiary.

The fourth construct is to investigate whether an organization evaluates or not the "impacts generated by the social projects" it sponsors.

The final construct considers the context of "place and the community" in the management of social projects. It considers the importance of the community in the development of the social project. The five constructs are illustrated in Fig. 1, where all variables used in the research are presented.

Table 4, complementary to Table 3, shows each of the variables associated with their constructs. Such variables and constructs are included in project management stakeholder participation since these variables can indicate the level of participation of stakeholders in processes.

This proposal has implications that will be discussed further. 


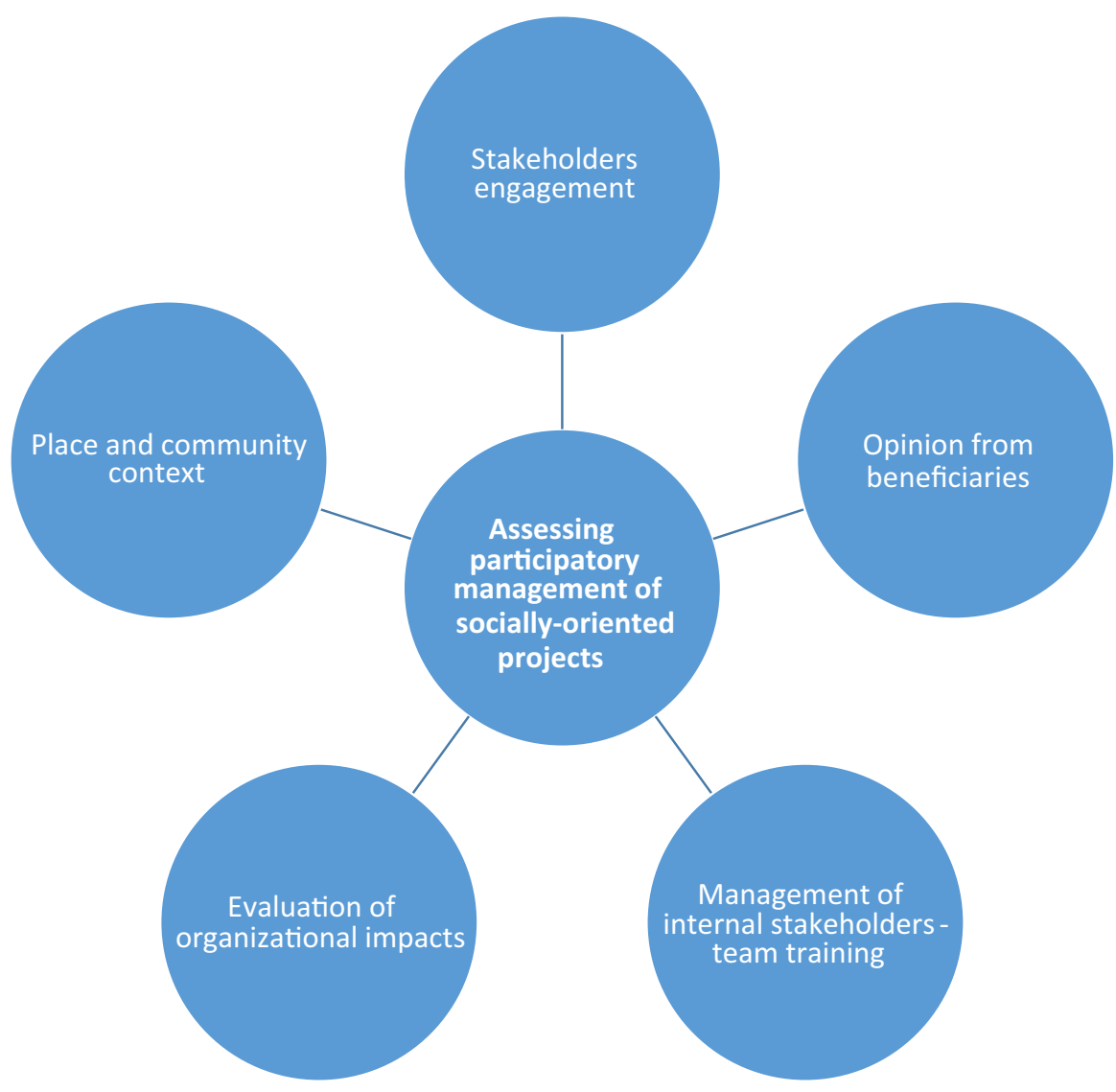

Fig. 1 Constructs considered when assessing stakeholders' participation in projects

\section{Summary and conclusion}

\subsection{Conclusion and implications}

The main contribution of this work is to develop a new framework that amalgamates constructs and variables which are relevant for managing socially-oriented projects, either within organizations (organizational social responsibility) or projects led by non-profit-organizations, such as humanitarian projects. The work aims to add to the literature by calling attention to the relevance of giving voice to stakeholders during execution of socially-oriented projects.

The framework has the following potential implications:

- For academics, it adds a perspective of constructs and variables relevant to assuring stakeholders' voice in socially-oriented projects.

- For people or organizations which invest and donate to social projects, the framework can be a useful way to check the level of stakeholders' engagement.

- For organizational responsibility projects, the framework seems to be comprehensive enough to provide a fair assessment of stakeholders' real engagement.

- For humanitarian projects, it adds a new perspective of stakeholder management. 
Table 3 Constructs, variables, and authors contributing to participatory management of corporate social projects Source Prepared by the author

\begin{tabular}{|c|c|c|}
\hline Constructs & Variable (V) & Supporting literature \\
\hline Stakeholders' engagement & $\begin{array}{l}\mathrm{V} 1, \mathrm{~V} 2, \mathrm{~V} 3, \mathrm{~V} 4, \mathrm{~V} 5, \mathrm{~V} 6, \mathrm{~V} 7, \\
\mathrm{~V} 8, \mathrm{~V} 9, \mathrm{~V} 10\end{array}$ & $\begin{array}{l}\text { Buchholz and Rosenthal } \\
\text { (2005) } \\
\text { Purnell and Freeman (2012) } \\
\text { Harrison and Wicks (2013) } \\
\text { Valdes-Vasquez and Klotz } \\
\text { (2013) }\end{array}$ \\
\hline Opinion from beneficiaries & $\begin{array}{r}\text { V11, V12, V13, V14, V15, } \\
\text { V16, V17,V18,V19, V20 }\end{array}$ & $\begin{array}{l}\text { Sulbrandt (1994) } \\
\text { Clarkson (1995) } \\
\text { Weiss (1998) } \\
\text { Marrewijk (2003) } \\
\text { Rodrigues (2010) } \\
\text { Salazar et al. (2012) } \\
\text { Valdes-Vasquez and Klotz } \\
\text { (2013) }\end{array}$ \\
\hline $\begin{array}{l}\text { Management of internal } \\
\text { stakeholders-team training }\end{array}$ & $\begin{array}{l}\text { V21, V22, V23,V24, V25, } \\
\text { V26, V27 }\end{array}$ & $\begin{array}{l}\text { Buchholz and Rosenthal } \\
\text { (2005) } \\
\text { Valdes-Vasquez and Klotz } \\
\text { (2013) }\end{array}$ \\
\hline $\begin{array}{l}\text { Evaluation of organizational } \\
\text { impacts }\end{array}$ & $\begin{array}{l}\text { V28, V29, V30, V31, V32, } \\
\text { V33, V34, V35, V36, V37, } \\
\text { V38, V39, V40, V41, V42, } \\
\text { V43 }\end{array}$ & Gilbert and Rasche (2008) \\
\hline & & $\begin{array}{l}\text { Harrison and Wicks (2013) } \\
\text { Valdes-Vasquez and Klotz } \\
\text { (2013) }\end{array}$ \\
\hline Place and community context & $\begin{array}{l}\text { V44, V45, V46, V47, V48, } \\
\text { V49 }\end{array}$ & $\begin{array}{l}\text { Harrison and Wicks (2013) } \\
\text { Valdes-Vasquez and Klotz } \\
\text { (2013) }\end{array}$ \\
\hline
\end{tabular}

\subsection{Suggestion for a research agenda in operations management}

For the operations management community, it is possible to suggest the following research agenda:

- The framework can be improved further by adding elements of compassionate operations management and other emerging theories.

- The framework can be developed further, by creating metrics, assessment tools and pragmatic checklists.

- Maturity levels of stakeholders' engagement in socially-oriented and humanitarian operations can be understood.

- The framework can be useful for further mathematical models, surveys and optimization perspectives.

- Qualitative and in-depth studies can be conducted, through interviews and case studies. 
Table 4 Constructs and description of the variables that contribute to participatory management of corporate social projects Source Prepared by the author from Freeman (1984), Sulbrandt (1994), Weiss (1998), Buchholz and Rosenthal (2005), Rodrigues (2010), Salazar et al. (2012), and Valdes-Vasquez and Klotz (2013)

\begin{tabular}{|c|c|}
\hline Constructs & $\begin{array}{l}\text { Variables (V) extracted from theoretical articles of the Theory of } \\
\text { Stakeholders }\end{array}$ \\
\hline Stakeholders engagement & $\begin{array}{l}\text { (V1)__Organization concerned with the development of social } \\
\text { projects and involving stakeholders } \\
\text { (V2)_Frequency with which interactions are held with } \\
\text { stakeholders } \\
\text { (V3)_-Perception of integrity of the organization by interested } \\
\text { parties } \\
\text { (V4)_-Partnerships with local government in the development of } \\
\text { projects to assist the understanding of local needs } \\
\text { (V5)_-Stakeholder management plan } \\
\text { (V6)_-Inform the public about the progress and constraints in the } \\
\text { planning and design of the project } \\
\text { (V7)_Establishing partnership strategies for solving interpersonal } \\
\text { conflicts between the project participants } \\
\text { (V8)_-Documenting and sharing the lessons learned during the } \\
\text { planning stages and execution of the project between all } \\
\text { stakeholders } \\
\text { (V9)_Communicating with each group of stakeholders on } \\
\text { deliveries and results of projects carried out and new projects } \\
\text { intended } \\
\text { (V10)_-Reporting to stakeholders on the criteria for the } \\
\text { commissioning process of the main stakeholders. }\end{array}$ \\
\hline Opinion from beneficiaries & 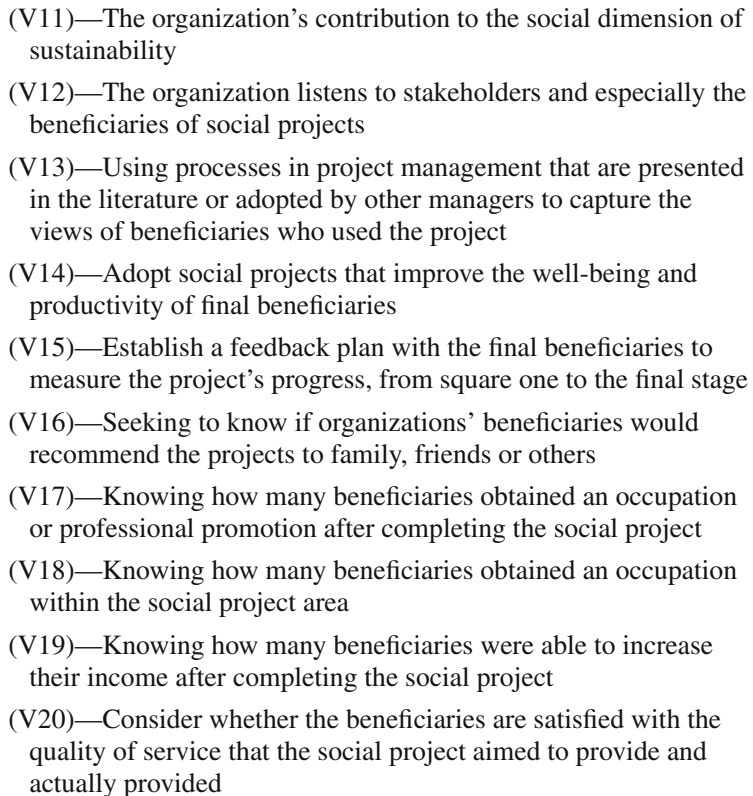 \\
\hline
\end{tabular}


Table 4 continued

Constructs
Variables (V) extracted from theoretical articles of the Theory of Stakeholders
Management of internal stakeholders - team training

Evaluation of organizational impacts
(V21)-Comprehensive stakeholder engagement with the organization so that the stakeholders are an integral part of their basic identity

(V22) - Select a team with a diverse profile, including participants from various professions, genders and races

(V23)-Include professionals specialized in the area of activity of the project into the work team to help analyze the impacts on the community and on end users

(V24)_Using the organization's managers in the projects, combining their skills with those of local professionals

(V25)—Build teams for projects, integrating them with stakeholders

(V26) - Consider the work skills of special groups of the community (women, unemployed, poor people, ethnic minorities, among others) and call them to work on social projects

(V27)-Assessing whether the administrative, organizational and staff functions are being well conducted

(V28)-Make an in depth assessment of the impacts of the project developed in all three dimensions of sustainability (social, economic and environmental)

(V29)_Undertake impact assessment in which internal stakeholders are heard (managers, staff and volunteers)

(V30)_Undertake impact assessment in which external stakeholders are heard (beneficiaries, family members)

(V31)_Undertake impact assessment considering also the opinion of other external stakeholders connected to the community (community leaders and institutions such as schools)

(V32)_Make an assessment of social impacts of the project in depth

(V33) - To analyze the effects of social projects to promote actions that encourage cultural and historical aspects of the community

(V34) - Incorporate social considerations (e.g., improvement of productivity and quality of life) in an impact analysis

(V35)_Assessing the impact of the introduction of new social classes in the community involved (for example, a low-income community can perceive the new social class working on projects as a threat based on stereotypes and misconceptions)

(V36)-Assess the subsequent results of the project compared to the evaluation of similar projects

(V37)_Analyze the impact of the project, identifying if there were any and what changes have taken place in the cultural and ethnic identity of the community involved

(V38) - To assess possible changes that are repeated periodically within the community andthat effects on employment patterns, business routines and community practices

(V39)_Analyze the impact of the project location on access to public transportation and the accessibility of the project to the population 
Table 4 continued

Constructs $\quad$ Variables (V) extracted from theoretical articles of the Theory of
Stakeholders

(V40) - Consider the evaluation of social projects and whether the management objectives and the supply of services relating to the offered social project are being achieved

(V41) - Consider whether, once the social project is started, the target number of beneficiaries was met

(V42)—Check whether or not services were delivered to the target public

(V43) - Consider in the social project evaluation whether there are people with needs (shortcomings/deficiencies) that are not being met (or served) by the social project.

Place and community context

(V44) - Number of meetings between community and organization

(V45) - Services that the organization provides to the community

(V46) - Contributions of the organization to charity and infrastructure

(V47) - Include privacy considerations for end users in the ratings they give to the project

(V48) -Evaluate the project planning decisions and partnerships in relation to the location of organizations / institutions near the area of the proposed project

(V49)-Develop a plan for the ongoing assessment of the project's impact on neighboring communities

- Comparative studies can test the suitability of the proposed framework in mature and less-mature economies.

- Understanding the failure of initiatives in engaging stakeholders in socially-oriented projects would be equally relevant.

\subsection{Limitations}

This work has limitations. Initially, it was based on a literature review, but not on a systematic one. A bibliometric study was not performed and the literature review is not to be considered comprehensive. Other models, frameworks and initiatives assessing the level of stakeholders engagement in socially-oriented and humanitarian operations were not comprehensively reviewed, as this was outside the scope of this work.

Open Access This article is distributed under the terms of the Creative Commons Attribution 4.0 International License (http://creativecommons.org/licenses/by/4.0/), which permits unrestricted use, distribution, and reproduction in any medium, provided you give appropriate credit to the original author(s) and the source, provide a link to the Creative Commons license, and indicate if changes were made.

\section{References}

AA1000 (2008). Accountability Principles Standard 2008. Recovered in April, 2011, of http://www. accountability21.net/uploadedFiles/publications/AA1000APS_Vers aoBrasiliera.pdf. 
Barbieri, J. C., \& Cajazeira, J. E. R. (2007). Responsabilidade social empresarial e empresa sustentável: da teoria à prática. São Paulo: Saraiva.

Buchholz, R. A., \& Rosenthal, S. B. (2005). Toward a contemporary conceptual framework for stakeholder theory. Journal of Business Ethics, 58(1-3), 137.

Carroll, A. B. (1979, october). A three-dimensional conceptual model of corporate social performance. Academy of Management Review, Georgia, 4(4), 497-505. Recovered in May 20, 2011, of http://www. kantakji.com/fiqh/Files/Companies/z119.pdf

Chanlat, J. (1995). In Davel, E. \& Vasconcelos, J. (Eds.), Recursos humanos e subjetividade. Petrópolis: Vozes.

Clarkson, M. B. E. (1995). A stakeholder framework for analyzing and evaluating corporate social performance. Academy of Management Review, 20(1), 92-117.

Coutinho, R. B. G., Macedo-Soares, T. D. L. V. A., \& Silva, J. R. G. (2006, setembro/outubro). Projetos sociais de empresas no Brasil: arcabouço conceitual para pesquisas empíricas e anàlises gerenciais. $R A P, 40(5)$, 763-787. Recovered in May 17, 2014, of http://www.scielo.br/pdf/rap/v40n5/a02v40n5.pdf>.

Dubey, R., \& Gunasekaran, A. (2016). The sustainable humanitarian supply chain design: Agility, adaptability and alignment. International Journal of Logistics Research and Applications, 19(1), 62-82.

Donaldson, T., \& Preston, L. E. (1995, january). The stakeholder theory of the corporation: Concepts, evidence, and implications. Academy of Management Review, 20(1), 65-91. Recovered in April 15, 2011, of http:// www.cbe.wwu.edu/dunn/rprnts.stakeholdertheoryofcorporation.pdf

Elkington, J. (2001). Canibais com garfo e faca. São Paulo: Makron Books.

Freeman, R. E. (1984). Strategic management: A stakeholder approach. Boston: Pitman.

Gaudeoso, E. C. S. (2014). Implementação e gestão de projetos sociais. Revista Pensamento \& Realidade., 29(2), 104-119.

Gilbert, D. U., \& Rasche, A. (2008). Discourse ethics and social accounting: The case of the global eight. In A. G. Scherer \& M. Patzer (Eds.), Betriebswirtschaftslehre und Unternehmensethik (pp. 291-313). Wiesbaden: Gabler.

Harrison, J. S., \& Wicks, A. C. (2013). Stakeholder theory, value and firm performance. Business Ethics Quarterly, 23(1), 97-124.

Leiras, A., de Brito, I, Jr., Queiroz Peres, E., Rejane Bertazzo, T., \& Tsugunobu Yoshida, Yoshizaki H. (2014). Literature review of humanitarian logistics research: Trends and challenges. Journal of Humanitarian Logistics and Supply Chain Management, 4(1), 95-130.

Marrewijk, M. V. (2003). Concepts and definitions of CSR and corporate sustainability: Between agency and communion. Journal of Business Ethics, 44, 95-105.

Project Management Institute. (2008). Um guia do conhecimento em gerenciamento de projetos [PMBOOK] (4th ed.). Newtown Square, PA: Author.

Purnell, L. S., \& Freeman, R. E. (2012). Stakeholder theory, fact/value dichotomy, and the normative core: How wall street stops the ethics conversation. Journal Business Ethics, 109, 109-116.

Roche, C. (2000). Avaliação de impacto dos trabalhos de ONGs. São Paulo: Cortez.

Rodrigues, M. C. P. (2010). Projetos sociais corporativos: Como avaliar e tornar essa estratègia eficaz. São Paulo: Atlas.

Salazar, J., Husted, B. W., \& Biehl, M. (2012). Thoughts on the evaluation of corporate social performance through projects. Journal of Business Ethics, 105(2), 175-186.

Santos, R. C. (2004). Mensurando valor e performance na prestação de serviços sociais. Gestão.Org-Revista Eletrônica de Gestão Organizacional,2(1), 36-49.

Sarkis, J. (2012). Models for compassionate operations. International Journal of Production Economics, 139(2), 359-365.

Sulbrandt, J. (1994). A avaliação de programas sociais: uma perspectiva crìtica dos modelos usuais. In B. KLIKSBERG (Comp.), Pobreza, uma questão inadiãvel (pp. 365-410). Brasĩlia: Enap,

Tenório, F. G. (2006). Responsabilidade Social Empresarial: teoria e pràtica (2nd ed.). Rio de Janeiro: Editora FGV.

Valdes-Vasquez, R., \& Klotz, L. E. (2013, january). Social sustainability considerations during planning and design: framework of processes for construction projects. Journal of Construction Engineering and Management, pp 80-89.

Weiss, C. (1998). Evaluation: methods for studying programs and policies (2nd ed.). New Jersey: Prentice Hall. 